\title{
Enhancing the Actual Effect of the Ideological and Political Education among College Students under the Guidance of the Concept of the Scientific Development
}

\author{
Anbo Zheng \\ Beihua University, Jilin, · Jilin, 132013
}

key words: ideological and political education; the concept of scientific development,;college students

\begin{abstract}
In new Era, an increasing number of new situations have been found in strengthening and improving ideological and political education,full of opportunities as well as obstacles, so effective measurements need to be grasped. From the perspective of the students themselves ,this paper ,under the concept of scientific development,focuses on enhancing college students' overall quality and training students to become the pillars of socialism with Chinese characteristics.

General Secretary Hu Jintao once pointed out: "a far-sighted nation always puts her attention on youth; a visionary political party always considers youth as an important force in historical development and social progress. Hence, the concept of scientific development is of great and farreaching significance in promoting healthy growth of young college students as well as building a socialist harmonious society and speeding up the grand goal of socialist modernization. In educational practice in universities, a fundamental method to improve ideological and educational education and cultivate excellent socialism builders and successors is integrating theory with practice, so that the concept of scientific developmentwill be curved on students' bones ,not fade away as time goes on.
\end{abstract}

\section{Guiding college students to have the pursuit of academic knowledge.}

Striving to study scientific knowledge is a basic but essential mission for college students, otherwise they will lose the substance for the shadow, not to mention scientific development for the whole society. As for us tutors, it is our responsibility to direct them overcoming difficulties and making every effort to enrich theoretical knowledge and practical skills in their specific academic areas. At the same time, good habits of study and positive study environment are another two key components in ideological and political education. Furthermore, regularity of social development brings new and higher requirements on college students: besides compulsory academic courses in school, the consciousness of lifelong learning can never be emphasized too much as well as the learning methods that are suitable for their own study habits. At the same time, the concept of scientific development are supposed to be applied into learning scientific knowledge in colleges: first of all, correct values and views on life is an essential prerequisite for hard working, among which views on value is one of the most significant factors. Secondly, grasping the inherent law of development under the guidance of philosophical viewpoint is considered as the premise of scientific spirit in research. Thirdly, a detailed and effective study plan exerts great influence on study results, so time management is a valuable learning skills to be grasped. Last but not least, the freshmen are key targeted group in terms of ideological and political education, because they are more eager to be influenced and nurtured. Once the proper views on life have been established, a meaningful and colorful college life will be in their palms in all likelihood. 


\section{Guiding college students to have appropriate behaviors.}

Talent evaluation criteria, that is putting great emphasis on morality with all-round development, is more and more comprehensive during these days full of competitive economy, cutting-edge technologies and constantly changing information updates. According to the concept of scientific development, besides research and scientific study, morality also represents an aspect of the core value of universities. To become a man with responsibility, sentiment and integrity, the 3 significant components in socialist core values,continues to be the fundamental task in ideological and political education. Meanwhile, an inevitable element in scientific overall development is to achieve selfeducation, self-management, self-restriction and self-service so that positive and creative characteristic will be formed eventually to promote their thinking patterns and ideological systems. There's an old saying that your dreams will come true one day, in which the most important part is the dream. That is to say, only with a positive attitude towards study and life will college students cultivate healthy habits and have a bright future.

\section{Guiding college students to be qualified socialist citizens .}

A practical application of the concept of scientific development in colleges is to nurture all-round talents. In other words, the idea of "how to be a talent" has been in the limelight and arouses a heated debate among scholars who are particularly concern about it. First of all, motivation plays a vital role among young adults, especially when obstacles and difficulties involved. Hence, dialectics is a basic and useful thinking method to motivate young people to overcome negative emotion and feel enthusiastic about their study. Secondly, cognition,or self-evaluation exerts great influence on college students, which means a better understanding of some basic questions, such as "who you are, what is your dream and what can you do with your dream" allows college students to have better preparation for the next stage, particularly for their future career. Last but not least, the moral code, such as honest, righteous and loyal to Chinese Communist Party is essential in building a harmonious society. Therefore, college students have every right to be educated to become citizens with basic legal knowledge and high moral standard especially in an environment full of fierce competition and dilemmas.

\section{Guiding college students to have basic Moral Code and a healthy lifestyle.}

The first essential meaning for the concept of scientific development is to develop. in terms of college students, to develop their country will not come true without academic knowledge and basic moral code. to be specific, several aspects are involved: first, sense of norms enjoys vital importance in ideological and political education, such as honesty, which is the traditional virtues of the Chinese nation and is the market economy as well as the basic guarantee for the healthy development of Chinese citizens. Second, it is necessary to create a favorable environment and encourage students to take participate in physical training for the simple reason that according to several studies regular exercises are beneficial to their brain and self-esteem as well . Third, appropriate strategies ought to be used in ideological and political education, in which innovative, elaborate and comprehensive education strategies play prominent roles. Further explanations are as follows: we have entered the era of electronic information, so college students are in face of unprecedented new challenges so it is our tutors' responsibility to help students cultivate the power to address them. Furthermore, the devil's in the detail and attitude decides everything. To be a 
successful and competitive employees in the job market, meticulous and thoughtful trait can never be overestimated. Policy of every period all emphasize that we should develop students' sense of collectivism because it is the core of cooperation.

In conclusion, ideological and political education in colleges should base on the concept of scientific development and take students' overall-all development as the priority. At the same time, the overall coordination and sustainable development of college students is the aim of ideological and political education. With the help of the socialist core value system, it is the tutors' responsibility to educate the students to become well-qualified citizens according to the requirement of socialism.

\section{References:}

[1]Ji Zhou. Seize the opportunities and improve the ideological and political education of college students. [J]. Journal of Ideological and Theoretical Education.2004 (11)

[2]Tizheng wang, Jijun Zhang, Developing the socialist core value system among college students [J]Higher Education In China. 2007(9)

[3]Ge Hao.Apply the socialist core value into the practice of nurturing the college students[J] Higher Education in China.2007(9)

[4]Maochun Cao,An innovative thinking of the ideological and political education of college students under the guidance of the concept of scientific development.[J]. 2006(5)

[5]Wen Chen, An application of the concept of scientific development in to the ideological and political education[J]. Popular Science. 2007(1) 